\title{
Phytoestrogens: A Possible Agent for Controlling Fertility
}

\author{
Anugrah Ray and Debjani Nath* \\ Department of Zoology, University of Kalyani, India
}

Submission: January 16, 2018; Published: March 19, 2018

*Corresponding author: Debjani Nath, Department of Zoology, University Of kalyani, Kalyani Nadia, West Bengal, India, Tel: 91-33-9433384571; Email: nath_debjani@yahoo.co.in

\begin{abstract}
Phytoestrogens are naturally occurring non-steroidal estrogenic compounds. They are structurally similar to endogenous $17 \beta$-estradiol but the relative potency is significantly lower than that of steroidal estrogens. They are common constituents of human and animal diet. Soy is a common and very rich source of phytoestrogens. Their regular consumption has been related to chemopreventive activities against various hormone-dependent cancers including breast and prostate and alleviation of some of the adverse consequences of menopause. However, they have been linked with potential adverse effects associated with impaired reproductive function in mammalian species.
\end{abstract}

Keywords: Phytoestrogens; Phytoestrogens and fertility; Estrogen receptor; Selective estrogen receptor modulators; Soy; Isoflavones

Abbreviations: ERs: Estrogenic Receptors; DES: Diethylstilbestrol; SERMs: Selective Estrogen Receptor Modulators

\section{Introduction}

Phytoestrogens are naturally occurring polyphenolic compounds. They are ubiquitous in human and animal diet. Around 300 plants from more than 16 different plant families have been identified with such a kind of compounds [1,2]. They are structurally and/or functionally bear a close similarity to mammalian estrogens and their active metabolites. Though they are much less potent but their mode of action is similar to $17 \beta$-stradiol. The estrogenic compounds are widespread in food. They are found in herbs and seasonings (garlic, parsley), grains (soybeans, wheat, rice), vegetables (beans, carrots, potatoes), fruits (date, pomegranates, cherries, apples), and drinks (coffee) [3]. So only a totally plant-free diet would prevent exposure to them. We, the human beings as well as animals regularly expose to variable amounts of phytoestrogens mainly through diet. Soybean and soy-based products are the common source of their exposure. They are rich in isoflavones genistein and daidzein. In general, phytoestrogenic foods are generally considered safe for long-term, daily use but phytoestrogenic herbs and supplements, however, may not be safe for daily or long-term use for those women who are at high risk of developing estrogen-dependent cancers. These molecules are associated with reduced risk of breast and prostate cancers and lower postmenopausal effects like osteoporosis and cardiovascular diseases in Asian population. Studies also link that Asian populations have lower rates of hormone-dependent cancers (breast, endometrial) and lower incidences of menopausal symptoms and osteoporosis than Westerners. A diet rich in phytoestrogens is believed to be a contributing factor, as evidenced by numerous studies [3-6].

\section{Mode of action in target tissue}

They exert their estrogenic effects primarily via the estrogenic receptors (ERs) $\alpha$ and $\beta$, with a higher affinity for ER $\beta$ by approx. 30 fold. Hopert et al. have shown the affinity order for ER as17 $\beta$-estradiol>>>Coumestrol>genistein>daidzein>>> mangostin. Coumestrol is a fluorescent compound, most potent among phytoestrogens but still it is about 100-200 times less potent than $17 \beta$-estradiol and it is almost 3000 times less potent than diethylstilbestrol (DES). For estrogen receptor binding the phenolic ring is indispensable [7]. The ring of isoflavones mimics " $\mathrm{A}$ " ring of estrogens at the receptor binding site. They are of low molecular weight compounds similar to estrogen (MW272) and distance between two hydroxyl groups in the isoflavones nucleus is similar to that of estradiol with optimal hydroxylation pattern. They act as agonist, partial agonist and antagonist for ERs. When acting on estrogen receptors, they behave differently from estrogen and act like Selective Estrogen Receptor Modulators (SERMs). For example tamoxifen is used for the treatment of breast cancer. This drug stimulates estrogen receptors in the uterus and bone, but suppresses them in the breast $[8,9]$. 


\section{Physiological effects}

The first case of estrogenic activity dates back to the 1940's. It was documented as a clover disease in sheep. Australian ewes grazing on red clover rich pastures suffered from a severe reproductive disorder that resulted in high rates of infertility, abortion, and reproductive abnormalities in their offspring. It was reported by Bennetts et al. and attributed to an estrogen or its precursor. Later researchers linked the cause of infertility to isoflavones genistein and daidzein and their precursor's biochanin A and formononetin as components of the clover. Millington et al. reported that the formononetin content, not the biochaninA or genistein content, was positively correlated with the estrogenicity of the clover. Further research led to the identification of equol in the urine of sheep. Equol was responsible for the estrogenic effects observed in sheep [10]. A second case was observed in 1985 in the North American zoos. And this time it was a group of captive cheetah population. Light microscopy of liver tissues showed a vascular lesion that was characterized by partial or total occlusion of the centrilobular and sublobular hepatic veins with loosely arranged to dense fibrous connective tissues. The normal diet consisted of a commercially prepared feline diet and the ingredients included were horse meat, horse meat by-products, soybean product, bone meal, liver, fish meal, and a variety of vitamins and trace minerals. Surprisingly, captive cheetah population at the DeWildt Cheetah Research and Breeding Centre in South Africa did not show clinical sign of liver damage.

A major difference between the North American and DeWildt captive cheetah populations was diet. Analysis of the commercial feline diet by HPLC and GC- chromatography revealed large amount of two phytoestrogens daidzein and genistein. Affected group of cheetahs were consuming $\sim 50 \mathrm{mg}$ /day of these weak estrogens. The plasma concentration of genistein in rats fed by a diet including $750 \mu \mathrm{g} / \mathrm{g}$ genistein was 2.2 micromole/L (conjugated plus free) and this concentration was sufficient to elicit estrogenic effects in ovariectomized rodents. Consumption of a standard phytoestrogen-containing diet $(210 \mu \mathrm{g} / \mathrm{g})$ also elicited a high estrogenic response in the uterus of immature rats. Male fetuses have adverse effects on testis function during development of these chemicals but results are contrasting and difficult to interpret $[11,12]$.

\section{Conclusion}

Since estrogen receptors are found throughout male reproductive organs and phytoestrogens show a tendency to bind and elicit signaling, we can make an approach to use some of them as male contraceptives. For this, we can target estrogen receptor, androgen binding protein, seminal vesicles and most but not least important structure the epididymis. If we succeed to find out a way to stop the maturation of sperm in the epididymis for transient period of time then definitely it will open a new method for male contraception of phytoestrogens origin.

\section{References}

1. Amsterdam A, Abu RN, Carter J, Krychman M (2005) Persistent sexual arousal syndrome associated with increased soy intake. J Sex Med 2(3): 338-340.

2. Beecher GR (2003) Overview of dietary flavonoids: Nomenclature, occurrence and intake. J Nutr 133(10): 3248-3254.

3. Kerdivel G, Habauzit D, Pakdel F (2013) Assessment and molecular actions of endocrine-disrupting chemicals that interfere with estrogen receptor pathways. Int J Endocrinol 1: 501851.

4. Khurana S, Ranmal S, Ben-Jonathan N (2000) Exposure of newborn male and female rats to environmental estrogens: delayed and sustained hyperprolactinemia and alterations in estrogen receptor expression. Endocrinology 141(12): 4512-4517.

5. Knight DC, Eden JA, Huang JL, Waring MA (1998) Isoflavone content of infant foods and formulas. J Paediatr Child Health 34(2): 135-138.

6. Kuiper GG, Lemmen JG, Carlsson B, Corton JC, Safe SH, et al. (1998) Interaction of estrogenic chemicals and phytoestrogens with estrogen receptor. Endocrinology 139(10): 4252-4263.

7. Liu Z, Kanjo Y, Mizutani S (2010) A review of phytoestrogens: Their occurrence and fate in the environment. Water Res 44(2): 567-577.

8. Mueller SO, Simon S, Chae K, Metzler M, Korach KS (2004) Phytoestrogens and their human metabolites show distinct agonistic and antagonistic properties on estrogen receptor (ER) and ER in human cells. Toxicol Sci 80(1): 14-25.

9. Nikov GN, Hopkins NE, Boue S, Alworth WL (2000) Interactions of dietary estrogens with human estrogen receptors and the effect on estrogen receptor-estrogen response element complex formation. Environ Health Perspect 108(9): 867-872.

10. Russo M, Russo GL, Daglia M, Kasi PD, Ravi S, et al. (2016) Understanding genistein in cancer: The good and the bad effects: A review. Food Chem 196: 589-600.

11. Setchell KDR, Clerici C (2010) Equol: History, chemistry, and formation. J Nutr 140: 1355S-1362S.

12. Santell RC, Chang YC, Nair MG, Helferich WG (1977) Dietary genistein exerts estrogenic effects upon the uterus, mammary gland and the hypothalamic/ pituitary axis in rats. J Nutr 127(2): 263-269. 

(C) Commons Attribution 4.0 License DOI: 10.19080/GJORM.2018.03.555621
Your next submission with Juniper Publishers will reach you the below assets

- Quality Editorial service

- Swift Peer Review

- Reprints availability

- E-prints Service

- Manuscript Podcast for convenient understanding

- Global attainment for your research

- Manuscript accessibility in different formats

( Pdf, E-pub, Full Text, Audio)

- Unceasing customer service

Track the below URL for one-step submission https://juniperpublishers.com/online-submission.php 